\title{
An association analysis between OXT genotype and milk yield and flow in Italian Mediterranean river buffalo
}

\author{
Alfredo Pauciullo ${ }^{1 *}$, Gianfranco Cosenza ${ }^{1}$, Roberto Steri ${ }^{2}$, Angelo Coletta $^{3}$, Lazzaro Jemma ${ }^{1}$, \\ Maria Feligini ${ }^{4}$, Dino Di Berardino ${ }^{1}$, Nicolò P. P. Macciotta ${ }^{2}$ and Luigi Ramunno ${ }^{*}$ \\ ${ }^{1}$ Department of Soil, Plant, Environment and Animal Production Science, University of Naples "Federico II", via Università 100, Portici, NA \\ 80055 Italy \\ ${ }^{2}$ Department of Animal Science, University of Sassari, via De Nicola 9, Sassari, 07100 Italy \\ ${ }^{3}$ Associazione Nazionale Allevatori Specie Bufalina, Via F. Petrarca 42-44 Località Centurano, Caserta, 81100 Italy \\ ${ }^{4}$ Istituto Sperimentale Italiano 'Lazzaro Spallanzani', Via Einstein, Cascina Codazza, LO, 26900 Italy
}

Received 16 September 2011; accepted for publication 23 November 2011; first published online 27 January 2012

\begin{abstract}
The aim of this study was to evaluate possible associations between three SNPs at the oxytocin locus (AM234538: g.28C > T; g.204A > G and g.1627G $>$ T) and two productive traits, milk yield and milkability, in Italian Mediterranean river buffaloes. Effects of parity, calving season and month of production were also evaluated. A total of 41980 test-day records belonging to 219 lactations of 163 buffalo cows were investigated. The allele call rate was $98 \cdot 8 \%$ and the major allele frequency for all the investigated loci was $0 \cdot 76$. The OXT genotype was significantly associated with milk yield $(P=0 \cdot 029)$. The TT genotype showed an average daily milk yield approximately $1.7 \mathrm{~kg}$ higher than GT buffaloes. Such a difference represents about $23 \%$ more milk/d. A large dominance effect $(-1 \cdot 17 \pm 0.43 \mathrm{~kg})$ was estimated, whereas the contribution of OXT genotype $\left(r_{\mathrm{OXT}}^{2}\right)$ to the total phenotypic variance in milk yield was equal to 0.06. The TT genotype showed higher values also for the milk flow, even though the estimated difference did not reach a level of statistical significance $(P=0 \cdot 07)$. Such an association, among the first reported for the oxytocin locus in ruminants, should be tested on a population scale and possible effects on milk composition traits should be evaluated in order to supply useful indications for the application of marker-assisted selection programmes in river buffaloes.
\end{abstract}

Keywords: Mediterranean river buffalo, oxytocin gene (OXT), milk yield, marker assisted selection.

The Italian buffalo dairy industry has increased in the last fifty years mainly owing to the growing economic importance of its main product, the mozzarella PDO (Protected Denomination of Origin - Reg. EC 510/2006) cheese. In the last decade the Italian buffalo stock has almost doubled (http://www.aia.it), with approximately 344000 Mediterranean river buffaloes (Bubalus bubalis) farmed in Italy at present. Most of the herds, about 2500, are located in the south of the Country (http://agri.istat.it).

Such an increase of economic relevance has not being accompanied by an improvement of the production level of the animals. Average milk yield per buffalo cow is $2180 \pm 597 \mathrm{~kg}$ in $270 \mathrm{~d}$ of lactation (it was $2140 \mathrm{~kg}$ in the year 2000) with $8.45 \%$ fat and $4.59 \%$ protein (AIA, 2010). Although milk composition fits cheese processing

*For correspondence; e-mail: apauciul@unina.it; ramunno@unina.it requirements, the productive level is insufficient to satisfy the market demand and for meeting economic goals of farmers. Thus both management and breeding improvements are needed.

The Italian buffalo Herd book has 35114 registered buffaloes. Most of them are involved in a dairy recording programme. However, the implementation of a conventional breeding programme for dairy traits based on progeny testing and EBV calculation is hampered by the poor efficiency of $\mathrm{Al}$ in this species. Difficult oestrus detection and variability of its length are among the main causes (Barile, 2005; Drost, 2007). In fact, natural mating is the most widely used technique of reproduction. Moreover, small values of estimated genetic parameters have been ascribed to inaccurate identification of true paternity (Rosati \& Van Vleck, 2002).

Marker-assisted selection may represent a possible option for designing a suitable breeding scheme for Italian river buffaloes. Gene polymorphisms significantly associated 
with milk production traits may provide useful indications for identifying selection candidates with high genetic merit. Actually, few studies have been carried out on candidate genes in buffaloes. One example is represented by the association between $\alpha$-lactalbumin gene polymorphism and milk yield and composition (Dayal et al. 2009). More studies can be found on the molecular characterization of loci that may potentially affect dairy traits. Of particular interest is a polymorphism recently reported for the oxytocin (OXT) gene (Cosenza et al. 2007). This locus, mapped on river buffalo chromosome14q22 (lannuzzi et al. 2001), may be a possible candidate gene for improving milk yield and milkability, owing to the role of the oxytocin hormone in alveolar milk ejection and in milk flow rate. A successful milking requires a complete milk removal from both cisternal and alveolar compartments of the mammary gland. For a complete milk ejection, oxytocin must be released from the pituitary gland and transported to the udder where it acts on myoepithelial cells to promote contraction (Bruckmaier \& Blum, 1998). Milk ejection in response to suckling or milking is achieved via a classical neuro-endocrine process, known as the milk ejection reflex (Wakerley et al. 1994). This process is of particular importance for buffaloes, in which alveolar milk represents about $95 \%$ of total milk owing to the absence or small size of the udder cistern (Thomas et al. 2004; Caria et al. 2011).

The OXT gene is $912 \mathrm{bp}$ long and it codes for 106 amino acids of the oxytocin complex. Three SNPs have been discovered in Italian river buffalo: two transitions in the promoter 5'flanking region (AM234538: g.28C >T and g.204A>G) and a non-synonymous transversion (g.1627G $>\mathrm{T}$ ) at the 170th nucleotide of the second exon. The latter SNP is responsible for the $\mathrm{Arg}^{97} \rightarrow$ Leu amino acid substitution in the mature protein, which yields two alleles respectively named A (EMBL Acc. No AM234538) and B (EMBL Acc. No AM234539) (Cosenza et al. 2007).

The aim of the present work was to test possible associations between the above mentioned SNP polymorphisms at the OXT locus and milk yield in the Italian Mediterranean river buffalo.

\section{Materials and Methods}

DNA sampling and genotyping

Biological samples were collected from 170 Italian river buffaloes belonging to an experimental herd, located in Salerno province (Southern Italy). Sampling was carried out in collaboration with the Italian National Association of Buffalo Breeders (ANASB). DNA was extracted from blood leucocytes using the procedure described by Gossens \& Kan (1981).

Briefly, $5 \mathrm{ml}$ of frozen blood samples were washed twice with distilled water and $1.8 \% \mathrm{NaCl}$, protein digestion was carried out with $500 \mu \mathrm{l}$ of proteinase K solution $(2 \mathrm{mg} / \mathrm{ml}$ of proteinase $\mathrm{K}, 1 \% \mathrm{~W} / \mathrm{v}$ SDS and 0.02 $\mathrm{M}$-EDTA). Proteins were extracted using a phenol-chloroform method followed by
DNA precipitation with cold isopropanol. The isolated DNA was then resuspended in $100 \mu \mathrm{l} \mathrm{TE}$ buffer $\mathrm{pH} 7 \cdot 6(10 \mathrm{~mm}-$ Tris-1 mм-EDTA).

DNA concentration and $\mathrm{OD}_{260 / 280}$ ratio of the samples were then measured with the Nanodrop ND-2000C Spectrophotometer (Thermo Scientific). The entire panel of 170 animals was genotyped for three SNPs in out-sourcing (http://kbioscience.co.uk) using a competitive allele specific PCR system (KASPar), a novel form of homogeneous allelespecific fluorescent genotyping system based on Fluorescent Resonance Energy Transfer technology (FRET) and the use of VIC/FAM fluorochromes.

\section{Phenotypic data collection}

A total of 41980 test-day records belonging to 219 lactations of 163 buffalo cows of different parities (1-11) were used. Data were collected in the period January 2007-September 2009. Animals were milked twice a day with the Afifarm system (S.A.E. Afikim, Kibbutz Afikim, Israel). Milk yield and milk flow were recorded individually at each milking for the whole lactation through an Afi-Flo 2000 flow-meter. Only animals with complete genotyping for the three SNPs were retained for the statistical analysis. Average number of records per lactation was $192 \pm 97$.

\section{Statistical analysis}

Allelic frequencies were calculated for each SNP locus. Measures of linkage disequilibrium ( $\mathrm{D}^{\prime}$ and $r^{2}$ ) were estimated using Haploview software version 4.2 (http:// www.broadinstitute.org/haploview/haploview). Haplotype structure was defined according to Gabriel et al. (2002).

Associations between OXT polymorphisms for 163 buffaloes and milk yield and flow were investigated by fitting the following mixed linear model with the MIXED procedure of SAS 9.2 (2008):

$$
\begin{aligned}
y_{i j k l m n o}= & \mu+\text { Year }_{i}+\operatorname{Par}_{j}+\text { Sea }_{k}+\mathrm{OXT}_{l}+\mathrm{DIM}_{m} \\
& * \mathrm{OXT}_{l}+c_{n}\left(\mathrm{OXT}_{l}\right)+e_{i j k l m n o}
\end{aligned}
$$

where $y_{i j k l m n o}=$ milk yield or milk flow in test $\mathrm{o} ; \mu=$ overall mean; Year $_{i}=$ fixed effect of the $i$ th year of production (3); $\mathrm{Par}_{j}=$ fixed effect of the $j$ th parity ( 6 classes: 1 to $5,>5$ ); $\mathrm{Sea}_{k}=$ fixed effect of the $k$ th season (4); $\mathrm{OXT}_{l}=$ fixed effect of the /th OXT genotype; $\mathrm{DIM}_{m}=$ fixed effect of the $m$ th stage of lactation (30 intervals of $10 \mathrm{~d}$ each); $c_{n}=$ random effects of individual buffalo cow nested within oxytocin genotype $e_{i j k l m n o}=$ random residual.

The fixed effect of SNP genotype fits mean gene effect across the whole lactation. The days in milk (DIM) factor nested within OXT genotype was included in the model to estimate lactation curves of the different genotypes (Stanton et al. 1992). (Co)variance matrices of random effects of buffalo cow and residual were assumed to be diagonal, $\mathbf{I} \boldsymbol{\sigma}_{c}^{2}$ and $\mathbf{I} \sigma_{\mathrm{e}}^{2}$, respectively. They allow for the REML estimation of variance components associated to individual buffalo cow 
Table 1. Genotyping data, allele frequencies, Hardy-Weinberg equilibrium $(P \leqslant 0 \cdot 05)$, and absolute frequencies of buffalo cows, lactations and tests across genotypes of the three SNPs at the OXT locus

\begin{tabular}{|c|c|c|c|c|c|c|c|c|c|c|c|c|c|}
\hline \multirow{3}{*}{$\begin{array}{l}\text { EMBL acc. } \\
\text { no. } \\
\text { AM234538 }\end{array}$} & \multirow{3}{*}{$\begin{array}{l}\text { Position } \\
\text { Promoter }\end{array}$} & \multirow{2}{*}{\multicolumn{6}{|c|}{ Genotyping data }} & \multirow{2}{*}{\multicolumn{3}{|c|}{ Allele frequency }} & \multicolumn{3}{|c|}{ Absolute frequencies } \\
\hline & & & & & & & & & & & \multirow{2}{*}{ Cows } & \multirow{2}{*}{ Lactations } & \multirow{2}{*}{ Tests } \\
\hline & & & & g. 28 & & & & & & & & & \\
\hline & & & $\mathrm{CC}$ & $\mathrm{CT}$ & TT & TOT & $\%$ & C & $\mathrm{T}$ & $\mathrm{CC}$ & 93 & 122 & 23750 \\
\hline & & Obs. & 98 & 60 & 11 & 169 & $99 \cdot 4$ & 0.76 & $0 \cdot 24$ & $\mathrm{CT}$ & 60 & 82 & 15527 \\
\hline & & Exp. & $96 \cdot 95$ & $62 \cdot 11$ & $9 \cdot 95$ & & & \multicolumn{2}{|c|}{$\chi^{2}=0 \cdot 194$} & TT & 9 & 14 & 2445 \\
\hline & \multirow[t]{4}{*}{ Promoter } & \multicolumn{6}{|c|}{ g.204G >A } & & & & & & \\
\hline & & & $\mathrm{AA}$ & $\mathrm{AG}$ & GG & TOT & $\%$ & $A$ & G & AA & 93 & 122 & 23750 \\
\hline & & Obs. & 95 & 61 & 10 & 166 & $98 \cdot 2$ & 0.76 & $0 \cdot 24$ & AG & 60 & 82 & 15527 \\
\hline & & Exp. & $94 \cdot 88$ & $61 \cdot 24$ & $9 \cdot 88$ & & & \multicolumn{2}{|c|}{$\chi^{2}=0 \cdot 002$} & GG & 9 & 14 & 2445 \\
\hline & \multirow[t]{4}{*}{ Exon 2} & \multicolumn{5}{|c|}{ g.1627G > T } & & & & & & & \\
\hline & & & GG & GT & $\mathrm{TT}$ & TOT & $\%$ & G & $\mathrm{T}$ & GG & 94 & 123 & 23882 \\
\hline & & Obs. & 97 & 60 & 10 & 167 & $98 \cdot 8$ & 0.76 & $0 \cdot 24$ & GT & 60 & 82 & 15653 \\
\hline & & Exp. & $96 \cdot 58$ & $60 \cdot 84$ & $9 \cdot 58$ & & & $\chi^{2}=$ & 31 & $\mathrm{TT}$ & 9 & 14 & 2445 \\
\hline
\end{tabular}

$\left(\sigma_{\mathrm{c}}^{2}\right)$ and residual $\left(\sigma_{\mathrm{e}}^{2}\right)$. Statistical significance of the SNP effect was tested against variance of buffalo cow nested within SNP genotype according to repeated measures design theory (Littell et al. 1998). Pairwise comparisons among different levels of fixed effects included in the model were performed using a Bonferroni adjusted test.

The average gene substitution effect $(\alpha)$ was calculated using a mixed linear model with the same structure as (Eq. 1) but with the gene effect treated as a covariable, represented by the number of $\mathrm{G}$ alleles at the $\operatorname{OXT} \operatorname{locus}(0,1,2)$, and an interaction between alleles at the SNP locus to account for possible dominance effects (Banos et al. 2008).

Finally, in order to estimate the contribution of the oxytocin locus to the variance of the trait, a mixed model having the same structure of (Eq. 1) but with the OXT genotype treated as random was run. Thus a variance component associated with the OXT locus $\left(\sigma_{\text {OXT }}^{2}\right)$ was estimated. Contributions of OXT locus $\left(r_{\mathrm{OXT}}^{2}\right)$ and buffalo cow $\left(r_{\mathrm{c}}^{2}\right)$ to the total phenotypic variance of the trait considered were calculated as:

$r_{\mathrm{OXT}}^{2}=\frac{\sigma_{\mathrm{OXT}}^{2}}{\sigma_{\mathrm{OXT}}^{2}+\sigma_{\mathrm{C}}^{2}+\sigma_{\mathrm{e}}^{2}}$ and $r_{\mathrm{C}}^{2}=\frac{\sigma_{\mathrm{C}}^{2}}{\sigma_{\mathrm{C}}^{2}+\sigma_{\mathrm{e}}^{2}+\sigma_{\mathrm{OXT}}^{2}}$

\section{Results}

Genotype and allele frequencies together with distribution of buffalo cows, lactations and tests across different SNP genotypes are reported in Table 1. On average, the allele call rate was $98 \cdot 8 \%$. In all the three loci the major allele had a relative frequency of about 0.76 and $\chi^{2}$ values showed that there was no evidence for departure from the HardyWeinberg equilibrium $(P \leqslant 0 \cdot 05)$.

A complete linkage disequilibrium was observed. Average $\mathrm{D}^{\prime}$ and $r^{2}$ values were 1 and 0.97 respectively. Only two haplotypes were found: CAG and TGT with frequencies of 0.76 and 0.24 respectively, i.e. equal to allelic ones.
Table 2. Least squares means of milk yield $(\mathrm{kg} / \mathrm{d})$ and milking speed $(\mathrm{ml} / \mathrm{s})$ for the different levels of parity and calving season estimated with model (Eq. 1)

$\begin{array}{llclll}\text { Effect } & \text { Level } & \begin{array}{c}\text { Milk yield } \\ (\mathrm{kg} / \mathrm{d})\end{array} & \text { SE } & \begin{array}{l}\text { Milking flow } \\ (\mathrm{ml} / \mathrm{s})\end{array} & \text { SE } \\ \text { Parity } & 1 & 7 \cdot 18^{\mathrm{A}} & 0 \cdot 27 & 22 \cdot 35^{\mathrm{A}} & 0 \cdot 73 \\ & 2 & 8 \cdot 21^{\mathrm{B}} & 0 \cdot 28 & 21 \cdot 93^{\mathrm{B}} & 0 \cdot 78 \\ & 3 & 11 \cdot 17^{\mathrm{C}} & 0 \cdot 31 & 25 \cdot 86^{\mathrm{C}} & 0 \cdot 91 \\ & 4 & 13 \cdot 22^{\mathrm{D}} & 0 \cdot 37 & 27 \cdot 16^{\mathrm{D}} & 1 \cdot 25 \\ & 5 & 7 \cdot 97^{\mathrm{AB}} & 0 \cdot 48 & 21 \cdot 45^{\mathrm{AB}} & 1 \cdot 16 \\ & 6 & 9 \cdot 06^{\mathrm{BE}} & 0 \cdot 50 & 20 \cdot 33^{\mathrm{AB}} & 1 \cdot 39 \\ \text { Calving } & \text { Autumn } & 10 \cdot 04^{\mathrm{A}} & 0 \cdot 31 & 26 \cdot 59^{\mathrm{a}} & 1 \cdot 38 \\ \text { season } & \text { Winter } & 9 \cdot 49^{\mathrm{AB}} & 0 \cdot 27 & 21 \cdot 70^{\mathrm{ab}} & 1 \cdot 07 \\ & \text { Spring } & 9 \cdot 27^{\mathrm{AB}} & 0 \cdot 27 & 21 \cdot 79^{\mathrm{b}} & 1 \cdot 15 \\ & \text { Summer } & 9 \cdot 08^{\mathrm{AC}} & 0 \cdot 27 & 22 \cdot 62^{\mathrm{ab}} & 1 \cdot 07\end{array}$

$\mathrm{A}, \mathrm{B}, \mathrm{C}, \mathrm{D}$ Means within columns without a common superscript differ $(P<0 \cdot 01)$ ${ }^{\mathrm{a}, \mathrm{b}}$ Means within columns without a common superscript differ $(P<0 \cdot 05)$

Table 3. Least squares means of milk yield $(\mathrm{kg} / \mathrm{d})$ and milking speed $(\mathrm{ml} / \mathrm{s})$ for the genotypes at the locus g.1627G $>$ T of river buffalo oxytocin gene estimated with model (Eq. 1)

$\begin{array}{lclll}\begin{array}{l}\text { Oxytocin } \\ \text { genotype }\end{array} & \begin{array}{l}\text { Milk yield, } \\ \mathrm{kg} / \mathrm{d}\end{array} & \text { SE } & \begin{array}{l}\text { Milking speed } \\ (\mathrm{ml} / \mathrm{s})\end{array} & \mathrm{SE} \\ \text { GG } & 9 \cdot 28^{\mathrm{ab}} & 0 \cdot 27 & 22 \cdot 82 & 0 \cdot 77 \\ \text { GT } & 8 \cdot 69^{\mathrm{a}} & 0 \cdot 30 & 22 \cdot 12 & 0 \cdot 80 \\ \text { TT } & 10 \cdot 44^{\mathrm{b}} & 0.68 & 24 \cdot 60 & 1.63\end{array}$

${ }^{\mathrm{a}, \mathrm{b}}$ Means within columns without a common superscript differ $(P=0 \cdot 029)$

According to Gabriel et al. (2002), loci can be considered as being in the same haplotype block. Thus only one SNP (g.1627G > T) was considered in running model (Eq. 1).

Both milk yield and flow were significantly affected by all fixed factors included in model (Eq. 1) (Table 2), except for OXT genotype for milk flow (Table 3). Milk yield tended to increase from first to latter parities, reaching the maximum at 
Table 4. Substitution effect of a guanine for a thymine at the locus g.1627G $>$ T of the oxytocin gene (mean \pm SE) and contribution of the OXT locus at the total phenotypic variance

\begin{tabular}{|c|c|c|c|c|c|c|c|c|c|}
\hline Trait & $\alpha^{+}$ & $P$ & $d$ & $P$ & $\sigma_{\mathrm{OXT}}^{2}$ & $\sigma_{\mathrm{c}}^{2}$ & $\sigma_{\mathrm{e}}^{2}$ & $r_{\mathrm{C}}^{2}$ & $r_{\mathrm{OXT}}^{2}$ \\
\hline Milk yield, kg/d & $0 \cdot 58 \pm 0 \cdot 30$ & 0.054 & $-1 \cdot 17 \pm 0 \cdot 43$ & $0 \cdot 007$ & $0 \cdot 40$ & $4 \cdot 15$ & $2 \cdot 78$ & $0 \cdot 57$ & 0.06 \\
\hline Milking flow, $\mathrm{ml} / \mathrm{s}$ & $0 \cdot 89 \pm 0 \cdot 79$ & $0 \cdot 26$ & $-1 \cdot 59 \pm 1 \cdot 00$ & $0 \cdot 11$ & $1 \cdot 15$ & $21 \cdot 68$ & $187 \cdot 24$ & $0 \cdot 10$ & $0 \cdot 01$ \\
\hline
\end{tabular}

$+\alpha$ : Substitution effect; $d$ : dominance effect; $\sigma^{2}$ : variance components associated to the genotype (OXT); to the individual buffalo cow (c), to residuals (e); $r^{2}$ : contributions of genotype (OXT) and of individual buffalo cow (c) to the total phenotypic variance

the fourth calving. This parity order showed also the highest value for milk flow. Actually the two variables are highly correlated $(r=0.97)$. Largest daily milk yields were observed for buffaloes calving in autumn whereas lowest values were for summer calvings (Table 2). Moreover milk flow showed the highest values in the autumn calvings.

Contribution of the individual buffalo cow effect to the total phenotypic variance, also named repeatability (Stanton et al. 1992), was about $0 \cdot 57$ for milk yield and $0 \cdot 10$ for milk flow, respectively (Table 4).

The OXT genotype was significantly associated with milk yield ( $P=0.029)$ (Table 3$)$. In particular, TT buffaloes showed an average daily milk yield approximately $1 \cdot 7 \mathrm{~kg}$ higher than GT buffaloes (Table 3). Such a relevant difference, representing about $23 \%$ more milk/d, started at approximately $60 \mathrm{~d}$ of lactation and tended to remain constant throughout the whole lactation as it can be seen from the estimated lactation curves of the three genotypes reported in Figure 1. Compared with homozygous genotypes, GT buffaloes had a slightly lower average daily yield. A large dominance effect, statistically different from zero, was estimated. It is double the average substitution effect (Table 4). The contribution of OXT genotype $\left(r_{\mathrm{OXT}}^{2}\right)$ to the total phenotypic variance in milk yield was equal to 0.01 (Table 4).

The TT genotype showed highest values also for milk flow (20.8 and $14.7 \%$ more milk flow compared with GT and GG genotype respectively), even though the estimated difference did not reach a level of significance $(P=0 \cdot 07)$ (Table 3$)$. However, as for milk yield, also the milk flow curve was higher across the whole lactation for TT buffaloes (Fig. 2) compared with other genotypes. Also for this trait, an overdominance was evident (Table 3). The contribution of OXT genotype $\left(r_{\mathrm{OXT}}^{2}\right)$ to the total phenotypic variance in milk flow is lower than in the case of milk. This trend can be observed also for the individual contribution of the buffalo cow effect (Table 4).

\section{Discussion}

In this work, an association between three SNPs at the OXT locus and daily milk yield of Italian river buffalo is reported. Although the results refer to a single herd and should be tested population-wide, it is of great importance as one of the first indications of an association between a trait of economic importance and a candidate locus in this species. Moreover, it is among the first reports of an association between the

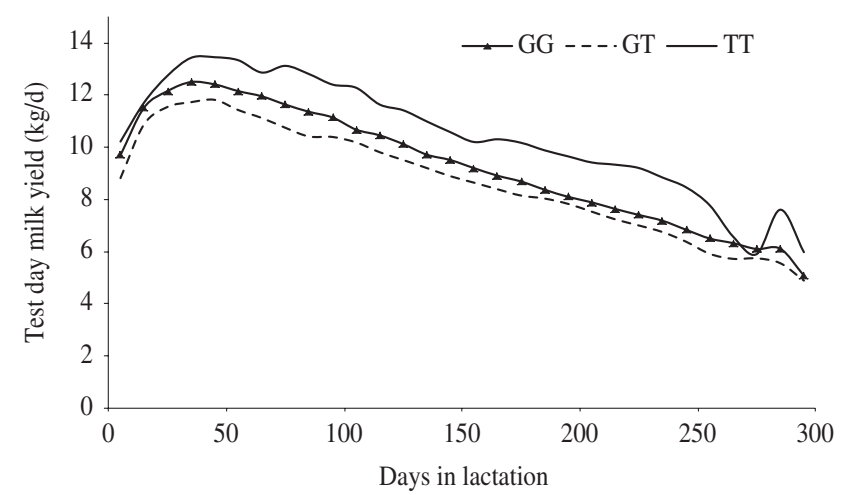

Fig. 1. Lactation curves of different $O X T$ genotypes for milk yield (kg/d). The GG genotype comprised 94 buffalo cows and 123 lactations, the GT 60 buffalo cows and 82 lactations, the TT 9 buffalo cows and 14 lactations, respectively.

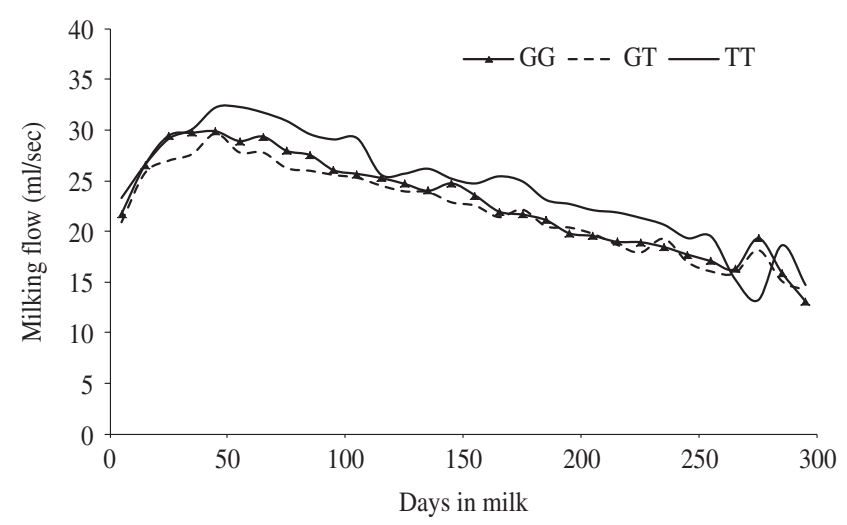

Fig. 2. Lactation curves of different $O X T$ genotypes for milking flow $(\mathrm{ml} / \mathrm{s})$. The GG genotype comprised 94 buffalo cows and 123 lactations, the GT 60 buffalo cows and 82 lactations, the TT 9 buffalo cows and 14 lactations, respectively.

oxytocin locus and production traits in ruminants. Therefore, it may offer useful indications for marker-assisted selection not only in buffaloes, but also for starting investigations in other dairy species.

\section{Environmental factors affecting milk traits}

Buffalo daily milk yield and flow were found to be significantly affected by parity, calving season and month of milking (Table 2). As expected, primiparous buffaloes 
showed a lower milk yield. The observed higher milk yield for third and fourth parities is in agreement with previous reports on Italian (Catillo et al. 2002) and Murrah (Dang et al. 2010) buffaloes. Moreover the milk flow tended to increase from first to later parities, even though with a less definite pattern, in agreement with results reported for dairy cattle (Pfeilsticker et al. 1996; Sandrucci et al. 2007; Guler et al. 2009). An effect of parity on milk flow and total milk volume has been reported also for the goat, where second and third lactation animals show higher values (Peris et al. 1996), whereas conflicting results have been observed for dairy sheep (Dell'Aquila et al. 1993; Sevi et al. 2000).

The relevant influence of seasonal effects on productive performances of buffaloes has been confirmed in the present work. The lowest average yield for calving in summer can be explained mainly by the depressive effect of high temperatures at the beginning of the lactation. Similar figures were obtained in Mediterranean and Pakistan Nili-Ravi breeds (Catillo et al. 2002; Afzal et al. 2007). The effect of calving season observed for milk flow, with highest flows for buffaloes that calve in autumn, is different from that reported for dairy cattle (Firk et al. 2002), and is probably due to the physiological and management differences between both species.

\section{Association between OXT genotype and milk traits}

The three SNPs at the OXT gene investigated in this study were found to be in the same haplotypic block. This was an expected result, given their close distance (only $1136 \mathrm{bp}$ separate the first and the last polymorphic site). The transversion g.1627G $>\mathrm{T}$ at the 170th nucleotide of the second exon responsible for the $\mathrm{Arg}^{97} \rightarrow$ Leu amino acid change was chosen for the association study. This SNP is in the same linkage phase with the g.204A $>$ G polymorphism in the promoter region of OXT gene, which is responsible for the presence/absence of a potential binding site for CCAAT/ enhancer binding protein-alpha (C/EBP alpha) (by TRANSFACT 7.0 database) (Cosenza et al. 2007). The C/ EBP alpha cooperates with other transcription factors, including pituitary-specific homeodomain protein (Pit-1), in the regulation of lactotropes gene transcription in the anterior pituitary. An effect of promoter polymorphism on milk production traits has been reported in cattle for the DGAT1 gene by Fürbass et al. (2006). Although a general action of enhancement of transcriptional activity might offer a possible explanation of the action of such OXT polymorphism on milk yield, further investigations are necessary.

The superiority in milk yield showed by TT buffaloes over the heterozygous genotype (more than $1.7 \mathrm{~kg} / \mathrm{d}$ ) is relevant compared with the relatively low level of production of this species. An interesting feature of such a difference is that it remains quite constant throughout the whole lactation. This feature has been observed also for other candidate genes found to affect dairy traits in cattle such as DGAT1 (Strucken et al. 2011), where the effect can be observed after 40 DIM, and SCD (Macciotta et al. 2008). The remarkable magnitude of the OXT effect is confirmed by its contribution to the total phenotypic variance of milk yield. The observed value is larger than the one reported for the DGAT1 (Grisart et al. 2002) but less than half of the contribution reported for the ABCG2 (Cohen-Zinder et al. 2005) genes on milk yield in dairy cattle.

The marked unbalance of genotype class data, with the best genotype represented by less than 10 buffalo cows demands great care in making inferences from the observed results. Actually, outliers may have a relevant impact on the estimated effect of the gene. Also the location of the investigated animals in a single herd should be mentioned. However, some elements have to be considered as possible counterbalances to the above mentioned drawbacks. Firstly, the large number of observations available per buffalo cow (about 200) that might have positively affected the accuracy of estimated differences. Secondly, the strictness of the statistical tests used. The approach used for testing the effect of the OXT prevents spurious statistical significances that may arise when the residual variance is used in denominator of the $F$ test. Moreover, the Bonferroni correction for the comparisons between the different genotype classes is very conservative. Finally, the common environmental and management conditions shared by the buffaloes might have allowed for a better control of some sources of nongenetic variation.

A large effect of dominance on milk yield was observed in the present work. In dairy cattle, dominance effects for milk production traits have been reported (Weller et al. 2003; Kuehn et al. 2007). Often dominant allele effects are not detected or considered not relevant, being numerically much lower than the additive effects, even though they might have an impact on allele substitution effects in the population.

Results for milk flow are of a lower magnitude as far the effect of the gene is concerned. Its contribution to the total phenotypic variance in milk flow is markedly lower than in the case of milk. This trend can be observed also for the individual contribution of the buffalo cow effect. Such a result is quite unexpected, considering the physiological role of oxytocin and the correlation between milk yield and ejection. However, it should be remembered that previous studies carried out in buffalo and cow highlight that it is the increase of the oxytocin level over a threshold that affects milk ejection and not its absolute concentration (Schams et al. 1984; Thomas et al. 2005a). Thus a possible explanation may be that OXT genotype influences the total content of the hormone, but not its increase above the basal level. In any case, also the greater variability of milk ejection compared with milk yield (coefficient of variability 0.72 and $0 \cdot 43$, respectively) may be responsible for the lack of the statistical significance of the OXT genotype for this trait.

The estimated correlation among test-day milk yield within buffalo cow agrees with previous reports obtained on Italian river buffaloes (Catillo et al. 2002), whereas no information is available yet far for milk flow in such species. Therefore, the value for milk flow can be compared with results obtained in other species. In cattle, the repeatability of milk flow 
measurements has been estimated as 0.54 and 0.59 for Brown Swiss and Simmental breed, respectively (Ilahi \& Kadarmideen 2004), whereas in dairy sheep it was 0.50 (Marie-Etancelin et al. 2002). The lower value observed in the present work may be ascribed to the relevant effect of environmental noise. Buffaloes, in fact, are very sensitive even to small changes in the milking routine, and disturbed milk ejection occurs frequently (Thomas et al. 2005a,b). Accordingly, measurements within buffalo cow were not strongly related.

\section{Conclusions}

In recent years, a great deal of work has been done on Italian buffalo farms to improve recording, health, feeding and livestock systems. On the other hand, little has been done in terms of genetic improvement in this species.

In the present study, novel genotyping information and haplotype structure of a key gene involved in milk production were reported. A significant genetic association between three SNPs at the oxytocin locus and daily milk yield of Italian river buffalo was found. The genotype with selective advantage showed an average daily milk yield approximately $1.7 \mathrm{~kg}$ higher. Such a result, if confirmed population-wide, may be of great economic interest for the buffalo dairy industry. Increases in average milk yield and, consequently, in mozzarella PDO production may be expected.

The same polymorphisms showed a less defined effect on milk flow. Results suggest a need for further investigations on a wide number of herds. Milk production and milk flow were significantly affected also by parity, and calving season, confirming the seasonality of the productive performances of such species.

To our knowledge, this is one of the first indications of genetic association between a trait of economic importance in buffalo. Furthermore, it is among the first reports of an association between the oxytocin locus and production traits in ruminants. Therefore, it may offer useful indications for further analyses and application of marker-assisted selection programmes in other dairy ruminant species.

This work was financially supported by the Italian Ministry for Agriculture and Forestry Policy - MiPAAF (SELMOL project).

\section{References}

Afzal M, Anwar M \& Mirza MA 2007 Some factors affecting milk yield and lactation length in Nili-Ravi buffaloes. Pakistan Veterinary fournal $\mathbf{2 7}$ 113-117

AIA 2010 Milk recording activity: official statistics. In Annual Report of the Italian Breeders Association, p. 31 (Ed. Servizi Commerciali per gli Allevatori-SCA). Rome, Italy: Associazione Italiana Allevatori

Banos G, Woolliams JA, Woodward BW, Forbes AB \& Coffey MP 2008 Impact of single nucleotide polymorphisms in leptin, leptin receptor, growth hormone receptor, and diacylglycerol acyltransferase (DGAT1) gene loci on milk production, feed, and body energy traits of UK dairy cows. Journal of Dairy Science 91 3190-3200
Barile VL 2005 Improving reproductive efficiency in female buffaloes. Livestock Production Science 92 183-194

Bruckmaier RM \& Blum JW 1998 Oxytocin release and milk removal in ruminants. Journal of Dairy Science 81 939-949

Caria M, Murgia L, Pazzona A 2011 Effects of the working vacuum level on mechanical milking of buffalo. Journal of Dairy Science 94 1755-1761

Catillo G, Macciotta NPP, Carretta A, Cappio-Borlino A 2002 Effects of age and calving season on lactation curves of milk production traits in Italian water buffaloes. Journal of Dairy Science 85 1298-1306

Cohen-Zinder M, Seroussi E, Larkin DM, Loor JJ, Everts-van der Wind A, Lee JH, Drackley JK, Band MR, Hernandez AG, Shani M, Lewin HA, Weller JI, Ron M 2005 Identification of a missense mutation in the bovine ABCG2 gene with a major effect on the QTL on chromosome 6 affecting milk yield and composition in Holstein cattle. Genome Research $\mathbf{1 5}$ 936-44

Cosenza G, Pauciullo A, Mancusi A, Nicodemo D, Di Palo R, Zicarelli L, Di Berardino D, Ramunno L 2007 Mediterranean river buffalo oxytocinneurophysin I (OXT) gene: structure, promoter analysis and allele detection. Italian Journal of Animal Science 6 303-306

Dang AK, Mukherjee J, Kapila S, Mohanty AK, Kapila R, Prasad S 2010 In vitro phagocytic activity of milk neutrophils during lactation cycle in Murrah buffaloes of different parity. Journal of Animal Physiology and Animal Nutrition 94 706-711

Dayal S, Bhattacharya TK, Kaushik P, Singh SR 2009 Genetic typing of the alpha-lactalbumin gene and its association with milk production and 1 constituent traits in Indian riverine buffaloes. Buffalo Bulletin 28 11-17

Dell'Aquila S, Pilla AM, Catillo G, Scardella G, Taibi L 1993 Milk yield of Comisana, Delle Langhe, Massese, Sarda and crossbred ewes. Zootecnica Nutrizione Animale 14 95-102

Drost M 2007 Advanced reproductive technology in the water buffalo. Theriogenology 68 450-453

Firk R, Stamer E, Junge W, Krieter J 2002 Systematic effects on activity, milk yield, milk flow rate and electrical conductivity. Archives of Animal Breeding 45 213-222

Fürbass R, Winter A, Fries R, Kühn C 2006 Alleles of the bovine DGAT1 variable number of tandem repeat associated with a milk fat QTL at chromosome 14 can stimulate gene expression. Physiological Genomics 25 116-120

Gabriel SB, Schaffner SF, Nguyen H, Moore JM, Roy J, Blumenstiel B, Higgins J, Altshuler D 2002 The structure of haplotype blocks in the human genome. Science 296 2225-2229

Gossens M \& Kan JW 1981 DNA analysis in the diagnosis of haemoglobin disorders. Methods in Enzymology 76 805-817

Grisart B, Coppieters W, Farnir F, Karim L, Ford C, Berzi P, Cambisano N, Mni M, Reid S, Simon P, Spelman R, Georges M, Snell R 2002 Positional candidate cloning of a QTL in dairy cattle: identification of a missense mutation in the bovine DGAT1 gene with major effect on milk yield and composition. Genome Research 12 222-231

Guler O, Yanar M, Aydin R, Bayram B, Dogru U, Kopuzlu S 2009 Genetic and environmental parameters of milkability traits in Holstein Friesian cows. Journal of Animal and Veterinary Advances 8 143-147

Iannuzzi L, Gallagher DS, Di Meo GP, Schlapfer J, Perucatti A, Amarante MR, Incarnato D, Davis SK, Taylor JF, Womack JE 2001 Twelve loci from HSA10, HSA11 and HSA20 were comparatively FISH-mapped on river buffalo and sheep chromosomes. Cytogenetics and Cell Genetics 93 $124-126$

Ilahi H \& Kadarmideen HN 2004 Bayesian segregation analysis of milk flow in Swiss dairy cattle using Gibbs sampling. Genetic Selection Evolution 36 563-576

Kuehn C, Edel C, Weikard R, Thaller G 2007 Dominance and parent-oforigin effects of coding and non-coding alleles at the acylCoAdiacylglycerol-acyltransferase (DGAT1) gene on milk production traits in German Holstein cows. BMC Genetics 2462

Littell RC, Henry PR, Ammerman CB 1998 Statistical analysis of repeated measures data using SAS procedures. Journal of Animal Science $\mathbf{7 6}$ 1216-1231

Macciotta NPP, Mele M, Conte G, Serra A, Cassandro M, Dal Zotto R, Cappio Borlino A, Pagnacco G, Secchiari P 2008 Association between a 
polymorphism at the Stearoyl CoA Desaturase locus and milk production traits in Italian Holsteins. Journal of Dairy Science 91 3184-3189

Marie-Etancelin C, Casu S, Aurel MR, Barillet F, Carta A, Deiana S, Jacquin M, Pailler F, Porte D, Tolu S 2002 New tools to appraise udder morphology and milkability in dairy sheep. In Options Méditerranéennes A55 CIHEAM-IAMZ pp. 71-80 (Ed. D Gabiña \& S Sanna). Zaragoza, Spain

Peris S, Such X, Caja G 1996 Milkability of Murciano-Granadina dairy goats. Milk partitioning and flow rate during machine milking according to parity, prolificacy and mode of suckling. Journal of Dairy Research 63 $1-9$

Pfeilsticker HU, Bruckmaier RM, Blum JW 1996 Cisternal milk in the dairy cow during lactation and after preceding teat stimulation. Journal of Dairy Research 63 509-515

Rosati A \& Van Vleck LD 2002 Estimation of genetic parameters for milk, fat, protein and mozzarella cheese production for the Italian river buffalo (Bubalus bubalis) population. Livestock Production Science $\mathbf{7 4}$ 185-190

Sandrucci A, Tamburini A, Bava L, Zucali M 2007 Factors affecting milk flow traits in dairy cows: results of a field study. Journal of Dairy Science $\mathbf{9 0}$ 1159-1167

SAS STAT User's Guide, Version 9.2 Edition 2008. SAS Institute Inc., Cary, NC, USA

Schams D, Mayer H, Prokopp A, Worstorff H 1984 Oxytocin secretion during milking in dairy cows with regards to the variation and importance of a threshold level for milk removal. Journal of Endocrinology 102 $337-343$
Sevi A, Taibi L, Albenzio M, Muscio A, Dell'Aquila S 2000 Effect of parity on milk yield, composition, somatic cell count, renneting parameters and bacteria counts of Comisana ewes. Small Ruminant Research 37 99-107

Stanton TL, Jones LR, Everett RW, Kachman SD 1992 Estimating milk, fat, and protein lactation curves with a test day model. Journal of Dairy Science 75 1691-1700

Strucken EM, de Koning DJ, Rahmatalla SA, Brockmann GA 2011 Lactation curve models for estimating gene effects over a timeline. Journal of Dairy Science 94 442-449

Thomas CS, Bruckmaier RM, Östensson K, Svennersten-Sjaunja K 2005a Effect of different milking routines on milking-related release of the hormones oxytocin, prolactin and cortisol, and on milk yield and milking performance in Murrah buffaloes. Journal of Dairy Research 72 $10-18$

Thomas CS, Nordstrom J, Svennersten-Sjaunja K, Wiktorsson H 2005b Maintenance and milking behaviours of Murrah buffaloes during two feeding regimes. Applied Animal Behaviour Science 91 261-276

Thomas CS, Svennersten-Sjaunja K, Bhosrekar MR, Bruckmaier RM 2004 Mammary cisternal size, cisternal milk and milk ejection in Murrah buffaloes. Journal of Dairy Research 71 162-168

Wakerley JB, Clarke G, Summerlee AJS 1994 Milk ejection and its control. In The Physiology of Reproduction, pp. 1131-1177 (Ed. E Knobil \& JD Neill). New York: Raven Press

Weller JI, Golik M, Seroussi E, Ezra E, Ron M 2003 Population-wide analysis of a QTL affecting milk-fat production in the Israeli Holstein population. Journal of Dairy Science 86 2219-2227 